\title{
Mercury dynamics and mass balance in a subtropical forest, southwestern China
}

\author{
Ming Ma ${ }^{1}$, Dingyong Wang ${ }^{1,2}$, Hongxia Du ${ }^{1}$, Tao Sun ${ }^{1}$, Zheng Zhao ${ }^{1}$, Yongmin Wang ${ }^{1}$, and Shiqiang Wei ${ }^{1}$ \\ ${ }^{1}$ College of Resources and Environment, Southwest University, Chongqing 400715, China \\ ${ }^{2}$ Chongqing Key Laboratory of Agricultural Resources and Environment, Chongqing 400715, China \\ Correspondence to: Dingyong Wang (dywang@swu.edu.cn)
}

Received: 14 November 2015 - Published in Atmos. Chem. Phys. Discuss.: 21 December 2015

Revised: 23 March 2016 - Accepted: 29 March 2016 - Published: 13 April 2016

\begin{abstract}
The mid-subtropical forest area in southwest China was affected by anthropogenic mercury $(\mathrm{Hg})$ emissions over the past 3 decades. We quantified mercury dynamics on the forest field and measured fluxes and pools of $\mathrm{Hg}$ in litterfall, throughfall, stream water and forest soil in an evergreen broadleaved forest field in southwestern China. Total $\mathrm{Hg}(\mathrm{THg})$ input by the throughfall and litterfall was assessed at 32.2 and $42.9 \mathrm{\mu g} \mathrm{m}^{-2} \mathrm{yr}^{-1}$, respectively, which was remarkably higher than those observed from other forest fields in the background of North America and Europe. Hg fluxes across the soil-air interface $\left(18.6 \mathrm{mg} \mathrm{m}^{-2} \mathrm{yr}^{-1}\right)$ and runoff and/or stream flow $\left(7.2 \mu \mathrm{g} \mathrm{m}^{-2} \mathrm{yr}^{-1}\right)$ were regarded as the dominant ways for THg export from the forest field. The forest field hosts an enormous amount of atmospheric $\mathrm{Hg}$, and its reserves is estimated to be $25341 \mu \mathrm{g} \mathrm{m}^{2}$. The ratio of output to input $\mathrm{Hg}$ fluxes (0.34) is higher compared with other study sites. The higher output / input ratio may represent an important ecological risk for the downstream aquatic ecosystems, even if the forest field could be an effective sink of $\mathrm{Hg}$.
\end{abstract}

\section{Introduction}

Mercury ( $\mathrm{Hg}$ ) can cause damage to the environment and human health due to its extreme toxicity. It is well established that gaseous $\mathrm{Hg}$ can travel a long distance in the atmosphere so that aquatic systems in remote regions can be impacted by Hg pollution through deposition from the atmosphere (Lindberg et al., 2002a, b; Feng et al., 2009a, b). As a consequence, atmospheric deposition is the principal form of total $\mathrm{Hg}(\mathrm{THg})$ input to aquatic systems in remote pristine regions. Although $\mathrm{Hg}$ emissions must be reduced to mitigate current
Hg contamination in surface water and fish, the magnitude of that reduction is a critical policy debate.

Forest ecosystem is generally regarded as an active pool of $\mathrm{Hg}$. Hg transformation processes in the forest is considered a vital part of global Hg cycling (Ericksen et al., 2003; Sigler et al., 2009). Most of the $\mathrm{Hg}$ accumulated in canopy foliage comes from atmospheric sources, rather than root uptake (Ericksen et al., 2003; Stamenkovic and Gustin, 2009). The forest canopy is a major receptor of $\mathrm{Hg}$ in forested landscapes (St. Louis et al., 2001). The deposited Hg to the forest may produce a certain ecological risk on the biogeochemical cycle of $\mathrm{Hg}$ in the forest watersheds. $\mathrm{Hg}$ accumulated in the forest soil may be considered a source of both total and methyl $\mathrm{Hg}$ (MeHg) to aquatic ecosystems through runoff and/or stream flow. Moreover, $\mathrm{Hg}$ in the forest soil and decomposed litterfall can transfer into $\mathrm{MeHg}$, resulting in increased $\mathrm{MeHg}$ levels in downstream wet areas. Thus the release of $\mathrm{Hg}$ compounds from the forest field can be considered an initial step of $\mathrm{Hg}$ mobilization in forested catchments, and seems to be of high importance for its mobility.

Biogeochemical mass balance studies quantifying $\mathrm{Hg}$ pools and fluxes in the forest ecosystem are essential for assessing current rates of $\mathrm{Hg}$ inputs to, retention within, and release from terrestrial ecosystems. Major research initiatives have improved our understanding of current $\mathrm{Hg}$ pools and fluxes (Grigal et al., 2000; Schwesig and Matzner, 2001); however, knowledge of the internal cycling dynamics controlling retention within and release from these ecosystems which are located in the elevated $\mathrm{Hg}$ emitting regions is still limited (Demers et al., 2007). China's rapid economic development is predicted to increase the emission of atmospheric $\mathrm{Hg}$ (Fu et al., 2008, 2010a). The coal burning leads to Hg pol- 
lution in industrial and urban areas, as well as remote areas due to the long-range atmospheric transport of $\mathrm{Hg}$ (Feng and Qiu, 2008; Fu et al., 2009). In this study, we conducted a fullscale investigation on the distribution of $\mathrm{Hg}$ in the throughfall, litterfall and precipitation for a year. At the same time, we calculated the output and input of $\mathrm{Hg}$ during the study period. Thus, the objectives of this study were to (1) evaluate the deposition and output fluxes of $\mathrm{Hg}$ in the forest field and the accumulation of $\mathrm{THg}$ in a subtropical forest soil pool of southwest China, (2) discuss Hg import and export characteristics via deposition and runoff and/or stream flow in the study field, and (3) explore the main factors affecting $\mathrm{Hg}$ deposition, retention within and output fluxes in the subtropical forest ecosystem.

\section{Materials and methods}

\subsection{Site description}

We conducted this research at Mt. Simian National Natural Reserve $\left(106^{\circ} 22^{\prime}-106^{\circ} 25^{\prime} \mathrm{E}, 28^{\circ} 35^{\prime}-28^{\circ} 39 \mathrm{~N}\right)$, which is situated about $200 \mathrm{~km}$ away from Chongqing city (Fig. 1). Chongqing is the largest industrial city in southwest China, where combustion of coal accounted for more than $75 \%$ of the regional energy supplies in recent years. The study area has a subtropical monsoon climate, with abundant rainfall every year. The mean annual temperature is $13.7^{\circ} \mathrm{C}$, with the highest and lowest records in August (average: $31.5^{\circ} \mathrm{C}$ ) and January (averages: $-5.5^{\circ} \mathrm{C}$ ) respectively. The mean annual precipitation in the study area is $1522.3 \mathrm{~mm}$ with a daily maximum up to $160.5 \mathrm{~mm}$ (Lv et al., 2014). There are four seasons in Chongqing: spring (March to May), summer (June to August), autumn (September to November), and winter (December to February), with a well-defined wetwarm season from June to October. The study area is typical of the region with hills of $1394 \mathrm{~m}$ and watersheds of about $100.1 \mathrm{~km}^{-2}$. The evergreen broad-leaf forest selected in our research is believed to be one of the most representative vegetation types preserved in the study reserve due to the following reasons. First, it is one of the most complete forests located in the area between Chongqing and Guizhou. Second, it is almost all subtropical forest and until recent decades is one of Asia's least populated and most inaccessible areas. Third, it is the only largest and intact forest in the same latitude of the earth. Therefore, the evergreen broad-leaf forest was selected as the representative forest of subtropical vegetation in this research.

\subsection{Sampling methods and analysis}

\subsubsection{Sampling method of throughfall and precipitation}

The throughfall samples were obtained from the evergreen broad-leaf forest where $\mathrm{Hg}$ dynamics have been investigated for 1 year, from March 2012 to February 2013. The precipita-
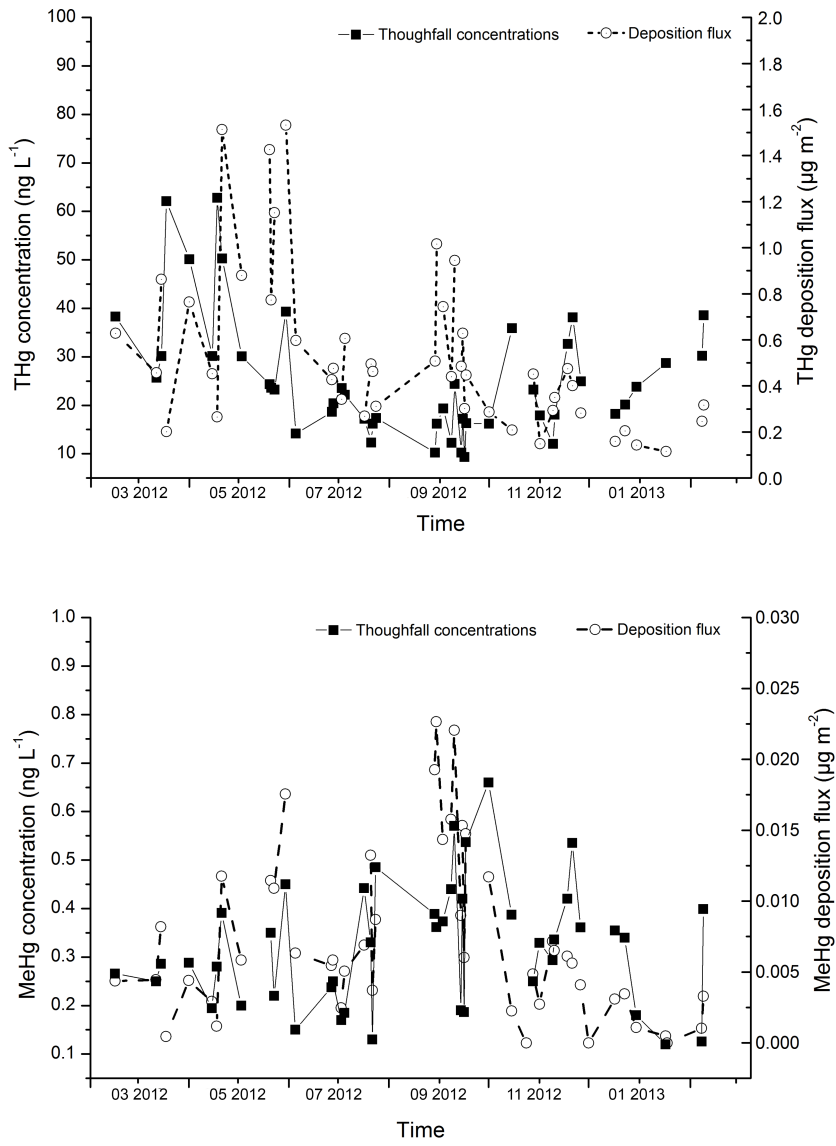

Figure 1. Volume-weighted mean concentrations of $\mathrm{THg}$ and $\mathrm{MeHg}$ and deposition fluxes of throughfall in the evergreen broad-leaf forest from March 2012 to February 2013.

tion samples were collected by automatic precipitation samplers (APS-3A, Changsha Xianglan Scientific Instruments Co., Hunan, China), which were placed on the forest field of the sampling site. The throughfall was collected and measured using the same rain gauges (APS-3A; Ma et al., 2015). Four rain gauges were randomly placed in each of the three $20 \times 20 \mathrm{~m}^{2}$ permanent observation plots in each plantation, resulting in 12 throughfall sampling points for each plantation. The containers were pre-washed with dilute $(5 \%) \mathrm{HCl}$ and thoroughly rinsed with deionized water after each sampling. Moreover, the throughfall and precipitation samples were collected after each precipitation event from each site during the sampling period.

The volume-weighted mean concentration (VWM) is obtained with the formula introduced in Acid Deposition Monitoring Network in East Asia, 2012:

$$
\begin{aligned}
\mathrm{VWM}= & \left(X_{1} \times V_{1}+X_{2} \times V_{2}+\cdots+X_{t} \times V_{t}\right) / \\
& \left(V_{1}+V_{2}+\cdots+V_{t}\right)=\sum\left(X_{t} \times V_{t}\right) / \sum V_{t},
\end{aligned}
$$


Table 1. Mean values of $\mathrm{THg}$ and $\mathrm{MeHg}$ concentrations and deposition fluxes in throughfall and litterfall.

\begin{tabular}{|c|c|c|c|c|c|c|}
\hline & \multicolumn{3}{|c|}{ THg Concentration $\left(\mathrm{ng} \mathrm{L}^{-1}\right)$} & \multicolumn{3}{|c|}{$\mathrm{MeHg}$ Concentration $\left(\mathrm{ng} \mathrm{L}^{-1}\right)$} \\
\hline & $\mathrm{THg}$ & $\mathrm{DHg}$ & $\mathrm{PHg}$ & $\mathrm{MeHg}$ & $\mathrm{DMeHg}$ & $\mathrm{PMeHg}$ \\
\hline Precipitation & $10.94 \pm 3.1$ & $4.43 \pm 2.2$ & $6.52 \pm 2.9$ & $0.24 \pm 0.34$ & $0.11 \pm 0.04$ & $0.13 \pm 0.10$ \\
\hline Throughfall & $24.04 \pm 7.9$ & $6.68 \pm 4.2$ & $16.35 \pm 5.7$ & $0.33 \pm 0.24$ & $0.25 \pm 0.12$ & $0.31 \pm 0.14$ \\
\hline Litterfall & \multicolumn{3}{|c|}{$\begin{array}{c}\text { THg Concentration }\left(\mathrm{ng} \mathrm{g}^{-1}\right) \\
106.7 \pm 18.3\end{array}$} & \multicolumn{3}{|c|}{$\mathrm{MeHg}$ Concentration $\left(\mathrm{ng} \mathrm{g}^{-1}\right)$} \\
\hline Annual deposition flux & \multicolumn{3}{|c|}{$\mathrm{THg}\left(\mu \mathrm{g} \mathrm{m}^{-2} \mathrm{yr}^{-1}\right)$} & \multicolumn{3}{|c|}{$\operatorname{MeHg}\left(\mu \mathrm{g} \mathrm{m}^{-2} \mathrm{yr}^{-1}\right)$} \\
\hline Precipitation $(1508 \mathrm{~mm})$ & \multicolumn{3}{|c|}{15.45} & \multicolumn{3}{|c|}{0.36} \\
\hline Throughfall (1336 mm) & \multicolumn{3}{|c|}{32.17} & \multicolumn{3}{|c|}{0.45} \\
\hline Litterfall $\left(402 \mathrm{~g} \mathrm{~m}^{-2} \mathrm{yr}^{-1}\right)$ & \multicolumn{3}{|c|}{42.89} & \multicolumn{3}{|c|}{0.32} \\
\hline
\end{tabular}

where $X_{t}$ means the ion concentration in each precipitation event (ng $\left.\mathrm{L}^{-1}\right), V_{t}$ means the volume of each rainfall (mm).

$\mathrm{Hg}$ flux was determined by multiplying $\mathrm{Hg}$ concentrations by the volume of precipitation collected. Wet deposition fluxes of $\mathrm{THg}$ and $\mathrm{MeHg}$ were calculated according to the following equation:

$F_{\mathrm{w}}=\frac{1}{1000} \sum_{i=1}^{i=n}\left(C_{R}^{i} P^{i}\right)$

where $F_{\mathrm{w}}$ is the annual $\mathrm{THg}$ or $\mathrm{MeHg}$ wet deposition flux $\left(\mathrm{mg} \mathrm{m}^{-2} \mathrm{yr}^{-1}\right), C_{i}$ is the VWM ( $\left.\mathrm{ng} \mathrm{L}^{-1}\right)$ of each rain sample, and $P_{i}(\mathrm{~mm})$ is the precipitation or throughfall amount.

\subsubsection{Sampling method of the stream}

The stream and/or runoff was collected at the edge of the forest catchment. For the water yield of the stream and/or runoff, it was monitored in the outlets of the forest catchment by the local hydrological departments. Stream water samples for analysis were collected in seven sampling sites every 2 weeks from March 2012 to February 2013. The $250 \mathrm{~mL}$ Teflon bottles were used to collect the stream water samples. All Teflon bottles were cleaned with detergent, thoroughly rinsed with tap water, boiled in a $30 \% \mathrm{HNO}_{3}$ solution $(v / v)$ for $1.5 \mathrm{~h}$, rinsed and filled with Milli-Q water. Trace-metal grade $\mathrm{HCl}$ was immediately treated to the samples to acidify them. It should be noted that the water samples were not filtered and thus represented the stream load of THg. The subtropical forest field in the study area is $100.1 \mathrm{~km}^{-2}$. Annual water discharge of the study site is $1.86 \times 10^{8} \mathrm{~m}^{3}$ (hydrological departments of Jiangjin district). The annual precipitation (Table 1) of the sampling site is slightly lower than the annual discharge. Therefore, it can be assumed that the calculation has a certain representativeness. Volume-weighted concentrations were computed by the stream/runoff collected during the study period. The fluxes were achieved by multiplying the average $\mathrm{Hg}$ concentration by the total amount of runoff during the study period.

\subsubsection{Sampling method of litterfall and soil pool}

The litter samples were collected by self-made litter collectors $(0.5 \mathrm{~m} \times 0.5 \mathrm{~m})$, which were made from treated lumber with a screen bottom. During the study period, the collectors were placed at four different sites within the study field. The litter collected was saved in brown paper bags and transported to the laboratory under $4{ }^{\circ} \mathrm{C}$, and then air-dried in a clean environment in the laboratory until analysis. Soil samples were collected at five different sites in each field using polyvinyl chloride pipes $(2.54 \mathrm{~cm})$. Soil samples were obtained from five soil profiles. Three layers $\left(O_{i}, O_{e}\right.$, and $O_{a}$ horizons) were collected from each profile according to diagnostic horizons. The average thickness of the organic soil horizon ( $O$ horizon) was $\sim 98 \mathrm{~cm}$. The $O_{i}$ and $O_{e} \mathrm{com}$ bined were $\sim 38 \mathrm{~cm}$ in thickness, and the $O_{a}$ horizon was $\sim 60 \mathrm{~cm}$. THg in the $O_{i}, O_{e}$, and $O_{a}$ horizons of the forest floor were based on two replicate soil cores from each of the five litter decomposition plots in each forest stand. After being freeze-dried, the samples were preserved in acid-cleaned polypropylene containers at room temperature until further analysis. Litter and soil collections were done monthly from March 2012 to February 2013.

\subsubsection{Hg volatilization from the forest field}

A dynamic flux chamber (DFC) in series with Tekran 1110 synchronized dual-port sampling unit and Tekran automated $\mathrm{Hg}$ analyzer (2537X) were used to measure the emission rates of $\mathrm{Hg}^{0}$ (Fu et al., 2010b). The special DFC method was described in detail in Ma et al. (2013). Hg emission fluxes were calculated by the equation below (Ma et al., 2013):

$F=\left(C_{\text {out }}-C_{\text {in }}\right) \times Q / A$,

where $F$ is the flux $\left(\mathrm{ng} \mathrm{m}^{2} \mathrm{~h}^{-1}\right) ; C_{\text {out }}$ and $C_{\text {in }}$ are $\mathrm{Hg}^{0}$ levels at the outlet and inlet of the $\mathrm{Hg}$ analyzer $\left(\mathrm{ng} \mathrm{m}^{3}\right) ; Q$ is the flushing flow rate through the chamber $\left(\mathrm{m}^{3} \mathrm{~h}^{-1}\right)$; and $A$ is the surface area of the soil exposed in the chamber $\left(\mathrm{m}^{2}\right)$.

$\mathrm{Hg}$ emission fluxes across the air-soil interface were monitored seasonally during eight intensive field campaigns from 
spring 2012 to winter 2013 (Spring: 4-16 March, 8-15 May 2012; Summer: 5-12 July, 15-22 August 2012; Autumn: 1522 September, 20-27 October 2012; Winter: 24-31 December 2012, 6-13 February 2013). Hg emission flux were monitored at three sampling sites in the evergreen broadleaved forest of Mt. Simian. Hg emission fluxes were measured continuously for 7 days for each sampling. Quality assurance was conducted by manually injected $\mathrm{Hg}$ to the ambient air and soil vapor of the Tekran analyzer before and after data collection. At the beginning and end of each measurement date, the Hg fluxes over a clean TeflonTM sheet in the field was measured and regarded as the chamber blanks. The chamber blanks in our research ranged from 0.48 to $0.64 \mathrm{ng} \mathrm{m}^{-2} \mathrm{~h}^{-1}$, with an average of $0.54 \pm 0.07 \mathrm{ng} \mathrm{m}^{-2} \mathrm{~h}^{-1}$ $(n=12)$. No blank value was needed to be subtracted from the flux due to no significant difference found.

\subsection{Sample analysis and quality control}

For $\mathrm{THg}$ and $\mathrm{MeHg}$ in water samples, the special method was described in Ma et al. (2015). Detailed introduction of the measurement of $\mathrm{THg}$ and $\mathrm{MeHg}$ in soil and litter samples can also be found in Ma et al. (2015).The detection limits of $\mathrm{THg}$ and $\mathrm{MeHg}$ in this research were 0.02 and $0.01 \mathrm{ng} \mathrm{L}^{-1}$ respectively. The dissolved total mercury $(\mathrm{DHg})$, dissolved methylmercury $(\mathrm{DMeHg})$, particulate $\mathrm{Hg}(\mathrm{PHg})$ and particulate $\mathrm{MeHg}(\mathrm{PMeHg})$ were analyzed following the EPA Method 1631 (US EPA, 1999).The method blank was lower than detection limits in all cases. And the equipment blanks for $\mathrm{THg}$ and $\mathrm{MeHg}$ were 0.04 and $0.02 \mathrm{ng} \mathrm{L}^{-1}$, respectively. The detection limits of Tekran $2537 \mathrm{X}$ was $0.1 \mathrm{ng} \mathrm{L}^{-1}$ for GEM. The average relative standard deviation for the duplicate analyses of $\mathrm{THg}$ and $\mathrm{MeHg}$ was 5.2 and $5.4 \%$, respectively. Matrix spikes recoveries for $\mathrm{THg}$ and $\mathrm{MeHg}$ were both within an acceptable range, 89 to $115 \%$ for $\mathrm{THg}$, and 91 to $117 \%$ for MeHg. Precision was determined by relative standard deviations. For duplicate samples, the precision was $5 \%$ for $\mathrm{THg}$ in water samples, $9 \%$ for $\mathrm{MeHg}$ in water samples, $8 \%$ for $\mathrm{THg}$ in soil samples, and $4.1 \%$ for $\mathrm{THg}$ in leaf tissues.

\section{Results and discussion}

\subsection{Hg concentrations and deposition fluxes in throughfall and litterfall}

$\mathrm{THg}$ concentrations in the throughfall ranged from 3.2 to $62.5 \mathrm{ng} \mathrm{L}^{-1}$ for the individual samples, and the average level of throughfall was $24.1 \pm 7.9 \mathrm{ng} \mathrm{L}^{-1}$. Canopy density did have an effect on $\mathrm{THg}$ and $\mathrm{MeHg}$ concentrations (the forest cover is more than $90 \%$ and the canopy density is 0.9$)$. THg concentrations measured in the throughfall of the subtropical evergreen broadleaved forest $\left(24.1 \pm 7.9 \mathrm{ng} \mathrm{L}^{-1}\right)$ were significantly higher than those measured in the open field $\left(10.9 \pm 3.1 \mathrm{ng} \mathrm{L}^{-1}\right)$. Similar to $\mathrm{THg}$ concentrations, $\mathrm{MeHg}$ concentrations in the throughfall were nearly 2.5 times higher than that in precipitation ( $p=0.004, n=49$ ).

$\mathrm{THg}$ concentrations in the throughfall were consistently at their highest in the cold season (Fig. 1), which was probably due to the lower rainfall but elevated atmospheric $\mathrm{Hg}$ in this season. In the subtropical region of China, the monsoondriven climate of northwest China does not bring much precipitation in the cold season. At the same time, atmospheric stability is high during the cold period, and pollutants like atmospheric $\mathrm{Hg}$ do not spread easily, which contributes to the higher scavenging ability of $\mathrm{Hg}$ in the atmosphere. The warm season (from April to September) is influenced by the southeast monsoon, and the rainfall increases greatly, which leads to lower concentration of $\mathrm{Hg}$ (Fig. 1). The study station has obscure seasons and clear rainy and dry seasons. The deposition fluxes of THg through throughfall also showed the seasonal variation characteristics, with higher fluxes appearing in the wet season (June to August). The deposition fluxes of THg through throughfall in summer at Mt. Simian accounted for more than $40 \%$ of total annual $\mathrm{Hg}$ deposition. However, it is still in September and October that a higher throughfall flux is observed. This may be because the rainfall in the 2 months is mainly effected by Indian Monsoon, contributing to a higher rainfall (Fu et al., 2010a) compared with other months. The minimum values for $\mathrm{THg}$ deposition occurred in the cold season.

During the surveillance, $\mathrm{THg}$ in the throughfall was evaluated to be $32.2 \mu \mathrm{g} \mathrm{m}^{-2} \mathrm{yr}^{-1}$. The deposition fluxes of $\mathrm{THg}$ through throughfall in Mt. Simian were lower than those investigated in the southwestern cities of China, such as Guizhou and Chongqing (Precipitation: 8.4$62.1 \mathrm{~g} \mathrm{~m}^{-2} \mathrm{yr}^{-1}$, throughfall: $15.6-292.1 \mu \mathrm{g} \mathrm{m}^{-2} \mathrm{yr}^{-1}$; Guo et al., 2008; Feng et al., 2009a, b; Wang et al., 2007). However, the deposition fluxes of THg through throughfall in Mt. Simian were approximately 2-10 times higher than those reported in remote areas of North America and Europe (Precipitation: $3.1-10.0 \mu \mathrm{g} \mathrm{m}^{-2} \mathrm{yr}^{-1}$, throughfall: 6.7$23.0 \mathrm{\mu g} \mathrm{m}^{-2} \mathrm{yr}^{-1}$; St. Louis et al., 2001; Keeler et al., 2005). Obviously, the THg fluxes at Mt. Simian were higher than other sites abroad. The reason perhaps was that Mt. Simian had considerably more dense forest canopies. As one of the National Natural Reserves of China, it has preserved the best subtropical evergreen broad-leaved forest of China. The forest cover in the reserves reaches over $90 \%$. The increased $\mathrm{THg}$ concentrations in throughfall mainly resulted from the dry deposition of $\mathrm{Hg}$ on the vegetation, followed by the washout of throughfall. Another possible reason for the elevated deposition fluxes, which may be the most important one, probably related to the increased atmospheric $\mathrm{Hg}$ concentrations in the past 30 years due to China's fast economic development. This area, especially Chongqing city, has a large demand for energy consumption, and about $70 \%$ of which is from coal combustion. The annual mean gaseous elemental $\mathrm{Hg}$ (GEM) concentration in the middle of Chongqing city (9.6-31.9 $\mathrm{ng} \mathrm{m}^{3}$; Wang et al., 2006), more 
than $200 \mathrm{~km}$ away from the study site, tripled compared with global background level (Lindberg et al., 2002a, b), which corresponded to the high annual deposition flux of $\mathrm{Hg}$ in the study area. It is also reported that the GEM concentration in the study area is as high as $3.8 \pm 1.5 \mathrm{ng} \mathrm{m}^{-3}$ (Ma et al., 2015), even if it is situated in a natural subtropical forest reserve. The $\mathrm{MeHg}$ flux was $0.45 \mu \mathrm{g} \mathrm{m}^{-2} \mathrm{yr}^{-1}$, which was higher than those measured in other areas. While $\mathrm{MeHg} / \mathrm{THg}$ in the throughfall samples was $1.3 \%$, which was a relatively high value compared with other studies (0.4$0.8 \%$; Lee et al., 2000; Demers et al., 2007; Choi et al., 2008; Fu et al., 2010a; Guo et al., 2008; Larssen et al., 2008). Here, the higher ratio of $\mathrm{MeHg}$ to $\mathrm{THg}$ in throughfall samples may suggest that the contribution of $\mathrm{MeHg}$ from throughfall cannot be ignored and should be taken care of in future studies. After all, accumulation of $\mathrm{MeHg}$ in the soil might have caused serious risks in the functioning of natural downstream ecosystems.

The deposition fluxes of THg through litterfall are shown in Table 1. The average concentrations of THg and $\mathrm{MeHg}$ in leaf litter were $106.7 \pm 18.3 \mathrm{ng} \mathrm{g}^{-1}(\mathrm{SE}=2.6, N=60)$ and $0.8 \pm 0.4 \mathrm{ng} \mathrm{g}^{-1}(\mathrm{SE}=0.2, N=60)$, respectively. The deposition flux of THg through litterfall was estimated to be $42.9 \mu \mathrm{g} \mathrm{m}^{-2} \mathrm{yr}^{-1}$ in the measurement field, which was remarkably higher than the input flux through throughfall. It is also considerably higher than litterfall fluxes reported from other regions (St. Louis et al., 2001; Demers et al., 2007). GEM can be absorbed by stomata and detained in the leaf tissue (Ericksen et al., 2003; Fu et al., 2008, 2010a). Therefore, we believed that the elevated litterfall input fluxes directly related to the increased GEM concentrations, even in remote areas.

\subsection{Mercury emission from soils under the canopy}

The emission characteristics and air-surface exchange of GEM from the subtropical forest field have been investigated during eight intensive field campaigns from 2012 to 2013. At the forest field, GEM released from soils had the characteristic of obvious diurnal and seasonal variations. Day and night GEM fluxes were statistically different $(t$ test, $p<0.001)$, with nighttime emissions considerably lower than that in daytime in all seasons (Fig. 2). Average fluxes of $\mathrm{Hg}$ in spring, summer, autumn and winter were $12.2 \pm 5.1,14.2 \pm 4.7,9.9 \pm 2.5$, and $3.1 \pm 1.1 \mathrm{ng} \mathrm{m}^{-2} \mathrm{~h}^{-1}$, respectively. It can be seen that the highest value occurred in summer, followed by spring and fall, while the lowest value was observed in winter. The average fluxes of $\mathrm{Hg}$ in spring $\left(12.2 \pm 5.1 \mathrm{ng} \mathrm{m}^{-2} \mathrm{~h}^{-1}\right)$ were slightly lower than that in summer $\left(14.2 \pm 4.7 \mathrm{ng} \mathrm{m}^{-2} \mathrm{~h}^{-1}\right)$, which was different from other studies (Larssen et al., 2008; Fu et al., 2010b). It appeared that warm temperature with low canopy density in spring at the mid subtropical forest was more likely to release GEM. Perhaps the primary reason lies in the fact that the forest canopies are lushly and well spaced in spring, and thus the forest can receive more sunlight. Therefore, the reduction rate of $\mathrm{Hg}^{2+}$ by photochemical, thermal and biogenic processes probably increased.

This research indicated that $\mathrm{Hg}$ fluxes of forest field were far lower than those observed from contaminated areas such as heavily air-polluted areas in eastern Guizhou (33$3638 \mathrm{ng} \mathrm{m}^{-2} \mathrm{~h}^{-1}$ ) (Wang et al., 2007), some cities in southwest China (15.0-44.4 $\mathrm{ng} \mathrm{m}^{-2} \mathrm{~h}^{-1}$ ) (Qiu et al., 2006), dry landfills (46.5-22.8 $\mathrm{ng} \mathrm{m}^{-2} \mathrm{~h}^{-1}$ ) (Zhu et al., 2010) and wetlands (20-500 $\mathrm{ng} \mathrm{m}^{-2} \mathrm{~h}^{-1}$ ) (Lindberg et al., 2002b). But the emission of GEM elevated in comparison with those reported from other places ( $-5.4-4.2 \mathrm{ng} \mathrm{m}^{3}$, Lindberg et al., 2002a, b; 1.7-8.4 $\mathrm{ng} \mathrm{m}^{3}$, Travnikov, 2005). At Mt. Simian, the estimated net GEM fluxes were released from soils during the warm season and slightly volatilized during the cold season. $\mathrm{Hg}$ deposition was only observed in several nights of the cold season during the study period. Hg released from the snowair interface was extremely low comparing with the soil-air interface. It was supposed that the $\mathrm{Hg}^{0}$ flux was zero from snow-covered surface (Huang et al., 2012). At most subtropical areas, especially mid-subtropical forests, however, there were short winter seasons with unstable snow cover, and the snow cover season only tended to occur in January. So we assumed that there still existed $\mathrm{Hg}^{0}$ emission in December and February in winter. Therefore, the annual total net $\mathrm{Hg}$ emission flux was $18.6 \mathrm{mg} \mathrm{m}^{-2} \mathrm{yr}^{-1}$.

\subsection{Hg concentrations and out-flux in stream water}

Annual volume-weighted concentrations of $\mathrm{THg}$ and $\mathrm{MeHg}$ were measured at the outlet stream of the forest field of Mt. Simian. The mean concentrations of $\mathrm{THg}$ and $\mathrm{MeHg}$ in the outflow stream were $3.9 \pm 2.0$ and $0.2 \pm 0.08 \mathrm{ng} \mathrm{L}^{-1}$, respectively. $\mathrm{THg}$ and $\mathrm{MeHg}$ concentrations in stream water draining the upland in our research were slightly higher than those reported in literature (Fu et al., 2008, 2010a; Larssen et al., 2008). THg concentrations in runoff and/or stream water in rainy seasons $\left(4.6 \pm 2.0 \mathrm{ng} \mathrm{L}^{-1}\right)$ were significantly higher than those in dry seasons $\left(3.3 \pm 1.8 \mathrm{ng} \mathrm{L}^{-1}\right)$, which can probably be attributed to the soil erosion and runoff (Ma et al., 2015). It is known that if a remote forest field does not have other obvious $\mathrm{Hg}$ pollution sources, $\mathrm{Hg}$ concentrations in the runoff and/or stream water can represent risks from a solitary watershed. Numerous studies showed that the catchments of remote forest were regarded as filters between atmosphere and hydrosphere (Lee et al., 2000; Larssen et al., 2008; Ericksen et al., 2003). The fate of $\mathrm{Hg}$ stored in the forest soils can be divided into three parts. One part of them transfers through food webs, threatening the balance of forest ecosystems; the second part of them is released into the atmosphere again; the third part of them probably transfers with the runoff and/or stream, becoming one of the $\mathrm{Hg}$ sources of downstream aquatic ecosystem. Therefore, to a certain extent, the role of forested catchments as $\mathrm{Hg}$ filters can be characterized by $\mathrm{Hg}$ output (runoff/stream) from the forest field. 

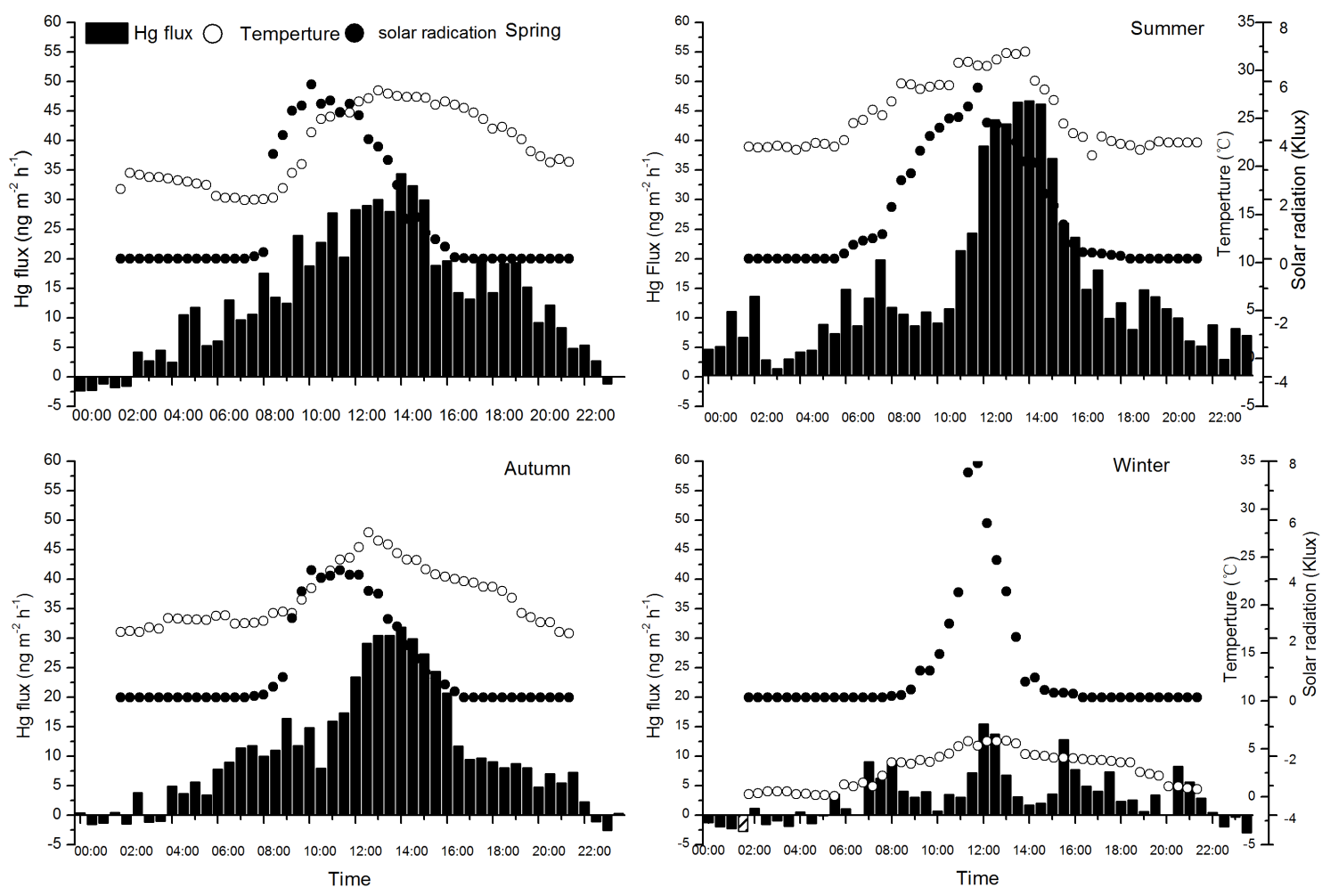

Figure 2. Soil emission fluxes of $\mathrm{Hg}$ and air temperature in the evergreen broad-leaf forest field. Spring: 4-16 March, 8-15 May 2012; Summer: 5-12 July, 15-22 August 2012; Autumn: 15-22 September, 20-27 October 2012; Winter: 24-31 December 2012, 6-13 February 2013.

This study showed that, even though $\mathrm{Hg}$ deposition fluxes in throughfall was high, $\mathrm{THg}$ concentration in stream and/or runoff was lower than that in contaminated sites under the same geological background. This indicated that subtropical forest field had the filtering effect of $\mathrm{Hg}$ in precipitation and throughfall. On the other hand, the lower concentration in stream and/or runoff indicated that the study area did not suffer from severe anthropogenic $\mathrm{Hg}$ pollution. Steam output of THg was calculated by multiplying the average THg concentration in stream water $\left(3.9 \pm 2.03 \mathrm{ng} \mathrm{L}^{-1}\right)$ by the water discharge rate in the forest field of the study site (annual water discharge: $1.86 \times 10^{8} \mathrm{~m}^{3}$, from hydrological departments of Jiangjin district). The export flux of THg via runoff and/or stream was $0.73 \mathrm{~kg} \mathrm{yr}^{-1}$. The subtropical forest field in the study area is $100.1 \mathrm{~km}^{-2}$. So the export flux of THg through stream water was $7.23 \mu \mathrm{g} \mathrm{m}^{-2} \mathrm{yr}^{-1}$, which tripled the values reported in the catchments of Sweden (1.6-1.8 $\mathrm{g} \mathrm{m}^{-2} \mathrm{yr}^{-1}$, Lee et al., 2000; $2.4 \mu \mathrm{g} \mathrm{m}^{-2} \mathrm{yr}^{-1}$, Larssen et al., 2008). Our results indicated that the output fluxes of $\mathrm{MeHg}$ via stream water were $0.08 \mu \mathrm{g} \mathrm{m}^{-2} \mathrm{yr}^{-1}$, which was similar to or slightly larger than other results $\left(0.03-0.07 \mu \mathrm{g} \mathrm{m}^{-2} \mathrm{yr}^{-1}\right.$, Lee et al., 2000; $0.05 \mathrm{\mu g} \mathrm{m}^{-2} \mathrm{yr}^{-1}$, Schwesig and Matzner, 2001). As we mentioned above that Mt. Simian was one of the most complete forest and until recent decades was one of Asia's least populated and most inaccessible areas. Aver- age $\mathrm{Hg}$ concentration in the soil detected in previous research was $0.28 \mathrm{mg} \mathrm{kg}^{-1}$ (Ma et al., 2013), which indicated that it was not an obvious geological Hg hotspot. Therefore, the elevated $\mathrm{Hg}$ fluxes in stream water were probably attributed to the great atmospheric $\mathrm{Hg}$ depositions. At the same time, our preliminary research results also illustrated that forest runoff and soil erosion could increase $\mathrm{Hg}$ output from subtropical forest catchments (Ma et al., 2013). But the total output fluxes of $\mathrm{THg}$ and $\mathrm{MeHg}$ were far lower than the input fluxes via wet deposition $\left(32.2 \mu \mathrm{g} \mathrm{m}^{-2} \mathrm{yr}^{-1}\right.$ for $\mathrm{THg}$ and $0.5 \mu \mathrm{g} \mathrm{m}^{-2} \mathrm{yr}^{-1}$ for MeHg). This study showed that the subtropical forest was able to exert purification effect of filtration, even under the condition of elevated deposition of $\mathrm{Hg}$.

\subsection{Dynamics and transport of $\mathrm{Hg}$ based on forest field}

THg content in the forest field (forest floor and soil profiles) of Mt. Simian was shown in Table 2. The THg stocked in the forest soil was approximately $20192 \mu \mathrm{g} \mathrm{m}{ }^{-2}$ (average soil depth is $98 \mathrm{~cm}$ ), while that in the organic floor was $5148 \mathrm{\mu g} \mathrm{m}^{-2}$ (average litter depth is $19 \mathrm{~cm}$ ). THg content in soil profile was three times more than the organic horizon in the subtropical forest field. The active pool (the upper $22 \mathrm{~cm}$, $O_{i}$ ) of THg represented $41 \%$ of the total storage of the study area. In the soil profile, THg content in the organic horizon $\left(O_{i}\right)$ is obviously higher than those in the other horizons. At 
Table 2. The concentrations and contents of THg in forest floor and different soil layers.

\begin{tabular}{|c|c|c|c|c|c|c|}
\hline & & $\begin{array}{r}\mathrm{THg} \\
\left(\mathrm{ng} \mathrm{g}^{-1}\right)\end{array}$ & $\begin{array}{r}\text { Density } \\
\left(\mathrm{g} \mathrm{cm}^{-3}\right)\end{array}$ & $\begin{array}{r}\text { Thickness } \\
(\mathrm{m})\end{array}$ & $\begin{array}{r}\text { THg content } \\
\quad\left(\mu \mathrm{g} \mathrm{m}^{-2}\right)\end{array}$ & Total contents \\
\hline \multirow{3}{*}{ Forest floor } & Initial leaf litter & $46.30 \pm 14.2$ & $0.28 \pm 6.2$ & $0.06 \pm 0.02$ & 774.8 & \multirow{3}{*}{5148.7} \\
\hline & Half decomposition & $51.22 \pm 9.4$ & $0.49 \pm 18.1$ & $0.08 \pm 0.03$ & 2000.8 & \\
\hline & decomposition & $57.88 \pm 10.3$ & $0.82 \pm 9.9$ & $0.05 \pm 0.02$ & 2373.1 & \\
\hline \multirow{3}{*}{ Soil profile } & $O_{i}$ & $297.8 \pm 15.2$ & $1.27 \pm 2.1$ & $0.22 \pm 0.10$ & 8320.5 & \multirow{3}{*}{20192.6} \\
\hline & $O_{e}$ & $117.4 \pm 32.3$ & $1.65 \pm 16.2$ & $0.34 \pm 0.08$ & 6586.1 & \\
\hline & $O_{a}$ & $68.4 \pm 13.6$ & $1.84 \pm 20.7$ & $0.42 \pm 0.06$ & 5286.0 & \\
\hline
\end{tabular}

the same time, the organic matter is well decomposed under a warm and rainy subtropical climate, which has high affinity to $\mathrm{Hg}$ in soil. Due to the good adsorption and reduction of organic matter, the organically bound contents of $\mathrm{Hg}$ could be released into the environment again during the decomposition of organic matter.

The ultimate fate of $\mathrm{Hg}$ in the terrestrial ecosystem may depend upon its delivery and incorporation into the forest floor. And the average $\mathrm{Hg}$ fluxes were also estimated. Input of THg to the forest field of Mt. Simian included net throughfall and litterfall depositions (St. Louis et al., 2001; Fu et al., 2010b). Annual throughfall and litterfall deposition fluxes of $\mathrm{THg}$ in Mt. Simian were 32.2 and $42.9 \mathrm{mg} \mathrm{m}^{-2} \mathrm{yr}^{-1}$, respectively (Fig. 3). Litterfall deposition inputs were estimated to be $134 \%$ of the throughfall deposition at the forest field. In the study forest field, the predominant pathway of $\mathrm{Hg}$ fluxes to the forest floor was via litterfall $(57.1 \%)$. A majority of atmospherically deposited $\mathrm{THg}$ was released through $\mathrm{Hg}^{0}$ at a rate of $18.6 \mu \mathrm{g} \mathrm{m}^{-2} \mathrm{yr}^{-1}$. Steam outflow of THg from the wetland was $7.2 \mu \mathrm{g} \mathrm{m}^{-2} \mathrm{yr}^{-1}$. The ratio between output and input of $\mathrm{THg}$ was 0.34 at the subtropical forest field of Mt. Simian, which was significantly higher than others (0.02-0.04, Lee et al., 2000; 0.16, Larssen et al., 2008; 0.30, Fu et al., 2010b). The apparently higher ratio between the output / input fluxes of THg may represent an important ecological risk.

The THg stored in the forest field was 982 times larger than the annual THg output by stream and/or runoff outflow and soil volatilization, and 338 times larger than the input estimated from wet and dry depositions (Fig. 3). The estimates of the deposition flux of THg in this study were much higher than values reported from northeastern American (3.8-12.6 $\mathrm{\mu g} \mathrm{m}^{-2} \mathrm{yr}^{-1}$; Driscoll et al., 2007) and Norway $\left(7 \mu \mathrm{g} \mathrm{m}^{2} \mathrm{yr}^{-1}\right.$; Larssen et al., 2008), probably indicating a significant impact of heavy regional $\mathrm{Hg}$ emissions from industry and urban on local $\mathrm{Hg}$ deposition. The reason perhaps was that highly soluble $\mathrm{Hg}^{2+}$ was easily stripped from the atmosphere and deposited locally. Higher wet deposition can illustrate the remarkable influence of local $\mathrm{Hg}$ emissions on $\mathrm{Hg}$ accumulation in the regional forest field. The $\mathrm{THg}$ flux through litterfall was 1.5 times larger than that through throughfall due to greater input of litter mass and higher $\mathrm{Hg}$

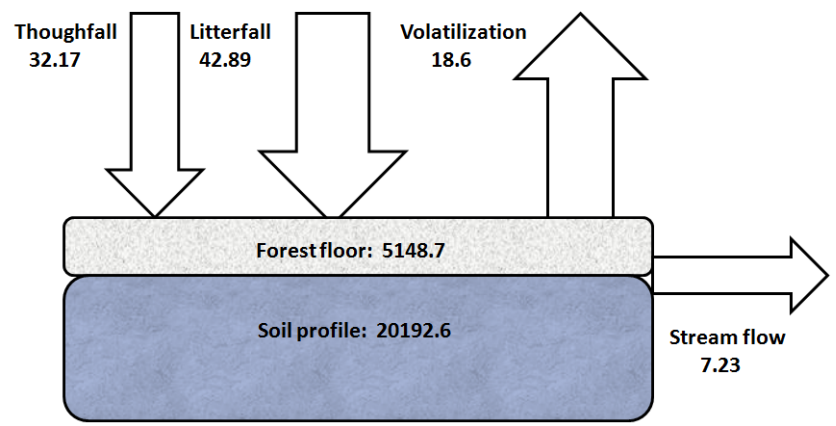

Figure 3. Annual ecosystem $\mathrm{Hg}$ fluxes and pools in the evergreen broad-leaf forest field. Fluxes $\left(\mu \mathrm{g} \mathrm{m}^{-2} \mathrm{yr}^{-1}\right)$ were represented by arrows, while pools $\left(\mu \mathrm{g} \mathrm{m}^{2}\right)$ by boxes.

concentrations in the litter. Annual exports of THg in stream water of the study area (3.2-9.5 $\mathrm{g} \mathrm{m}^{-2} \mathrm{yr}^{-1}$ ) were not accorded with those reported from northern forest catchments (1.0-3.4 $\mu \mathrm{g} \mathrm{m}^{-2} \mathrm{yr}^{-1}$; St. Louis et al., 2001; Grigal et al., 2000). An amount of the atmospherically deposited THg was lost via emissions at a rate of $18.6 \mu \mathrm{g} \mathrm{m}^{-2} \mathrm{yr}^{-1}$. Compared with stream outflow, the evasion of $\mathrm{Hg}$ from forest soil played a more essential role in THg outputs.

Compared to the ratios of output to input flux with other places (Larrsen et al., 2008; Fu et al., 2010b), the higher ratio may be greatly affected by the elevated deposition. Therefore, regional emission of $\mathrm{Hg}$ may have a stronger influence on forest ecosystems, in which the deposition of THg through litterfall and throughfall, being affected more by local and regional changes of $\mathrm{Hg}$ emissions and cycling, were the main paths for $\mathrm{Hg}$ entering into soil surface (Demers et al., 2007). However, in this study, the outflow of $\mathrm{Hg}$ via runoff output and the soil-air interface accounted for a small fraction of $\mathrm{Hg}$ budget in the study area. And the accumulation pattern of $\mathrm{Hg}$ in forest floor and soil profiles was seasonal. As we mentioned above that Mt. Simian was one of the most typical subtropical forest systems and the least accessed area, average $\mathrm{Hg}$ concentrations in all soil surfaces of this area were below $0.30 \mathrm{mg} \mathrm{kg}^{-1}$ (Fu et al., 2010b; Ma et al., 2013). Therefore, the accumulation of $\mathrm{Hg}$ in soil would be enhanced with time. At the same time, the ultimate fate of deposited $\mathrm{Hg}$ de- 
pends upon the biogeochemical processes that have not been well quantified within the ecosystem. $\mathrm{Hg}$ dynamics during litter decomposition, for instance, need to be considered as a whole so that we can better understand controls on long-term accumulation of $\mathrm{Hg}$ in the forest ecosystem and its delayed release to surface water.

\section{Conclusions}

In this study, the mass balance and transport of $\mathrm{Hg}$ in southwestern China were first measured at a subtropical forest, Chongqing, China. Results revealed that litterfall deposition inputs were the predominant pathway $\left(42.9 \mathrm{mg} \mathrm{m}^{-2} \mathrm{yr}^{-1}\right.$, account for $57.1 \%$ ) of $\mathrm{Hg}$ flux to the forest floor. Annual deposition fluxes of $\mathrm{Hg}$ through throughfall were $32.2 \mathrm{~m}^{-2} \mathrm{yr}^{-1}$, accounting for $42.9 \%$ of the $\mathrm{Hg}$ inputs. Researchers should pay more attention to the higher ratio of $\mathrm{MeHg}$ to $\mathrm{THg}$ in the throughfall deposition when they model the biogeochemical cycling in a typical local forest watershed. For the output process, the exchange of $\mathrm{Hg}\left(18.6 \mu \mathrm{g} \mathrm{m}^{-2} \mathrm{yr}^{-1}\right)$ across the forest field-air interface was an essential part of the biogeochemical cycle of $\mathrm{Hg}$. The runoff and/or steam outflow of THg from the wetland was $7.2 \mathrm{mg} \mathrm{m}^{-2} \mathrm{yr}^{-1}$, which was lower than that in contaminated sites under the same geological background. Therefore, we may conclude that (1) the study area does not suffer from severe anthropogenic $\mathrm{Hg}$ pollution; (2) the forested field has the filtering effect of $\mathrm{Hg}$ in precipitation and throughfall, even in the elevated atmospheric $\mathrm{Hg}$ area.

The forest field (forest floor and soil profiles) plays an important role in the cycling of $\mathrm{THg}$ and $\mathrm{MeHg}$. In reality, it is just another problem created by the accumulation of $\mathrm{Hg}$, which would be a potential risk affecting the output of $\mathrm{Hg}$ in the long term. Terrestrial ecosystems that have accumulated more $\mathrm{Hg}$ may ultimately emit them to the wetlands and surface water, finally affecting the entire aquatic ecosystems. Therefore, it is a signal that we should not ignore. In this case, however, any changes in the forest floor like deforestation or forestland degradation may strongly affect $\mathrm{Hg}$ budget of the region.

\section{Data availability}

Data in this research are available from the email of Professor D. Y. Wang, dywang@swu.edu.cn.

Author contributions. Ming Ma, Tao Sun, Hongxia Du and Zheng Zhao collected the litterfall, throughfall, stream water and forest soil samples. Yongmin Wang measured the concentrations of $\mathrm{THg}$ and $\mathrm{MeHg}$ from all samples. Tao Sun made the analysis of $\mathrm{Hg}$ volatilization from forest field. Ming Ma wrote the main manuscript text and drew all the figures, with contributions from all co-authors. Dingyong Wang, Shiqiang Wei and Ming Ma designed the research. All authors reviewed the manuscript.
Acknowledgements. We are also grateful to Vincent Grondin (University of Québec at Montreal) for his language modification on the early draft of the manuscript. This study was supported by the Natural Science Foundation of China (41573105), the National Basic Research Program of China (973 Program, 2013CB430003), and the Fundamental Research Funds for the Central Universities (XDJK2013B044).

Edited by: L. Zhang

\section{References}

Choi, H. D., Sharac, T. J., and Holsen, T. M.: Mercury deposition in the Adirondacks: A comparison between precipitation and throughfall, Atmos. Environ., 42, 1818-1827, doi:10.1016/j.atmosenv.2007.11.036, 2008.

Demers, J. D., Driscoll, C. T., Fahey, T. J., and Yavitti, J. B.: Mercury cycling in litter and soil in different forest types in the Adirondack region, New York, USA, Ecol. Appl., 17, 13411351, doi:10.1890/06-1697.1, 2007.

Driscoll, C. T., Han, Y. J., Chen, C. Y., Evers, D. C., Lambert, K. F., Holsen, T. M., Kamman, N. C., and Munson, R. $\mathrm{K}$.: Mercury contamination in forest and freshwater ecosystems in the northeastern United States, BioScience, 57, 17-28, doi:10.1641/B570106, 2007.

Ericksen, J. A., Gustin, M. S., Schorran, D. E., Johnson, D. W., Lindberg, S. E., and Coleman, J. S.: Accumulation of atmospheric mercury in forest foliage, Atmos. Environ., 37, 16131622, doi:10.1016/S1352-2310(03)00008-6, 2003.

Feng, X., and Qiu, G.: Mercury pollution in Guizhou, Southwestern China - an overview, Sci. Total Environ., 400, 227-237, doi:10.1016/j.scitotenv.2008.05.040, 2008.

Feng, X., Jiang, H., Qiu, G., Yan, H., Li, G., and Li, Z.: Mercury mass balance study in Wujiangdu and Dongfeng reservoirs, Guizhou, China, Environ. Pollut., 157, 2594-2603, doi:10.1016/j.envpol.2009.05.024, 2009a.

Feng, X., Jiang, H., Qiu, G., Yan, H., Li, G., and Li, Z.: Geochemical processes of mercury in Wujiangdu and Dongfeng reservoirs, Guizhou, China, Environ. Pollut., 157, 2970-2984, doi:10.1016/j.envpol.2009.06.002, 2009b.

Fu, X., Feng, X., Zhu, W., Wang, S., and Lu, J.: Total gaseous mercury concentrations in ambient air in the eastern slope of Mt. Gongga, South-Eastern fringe of the Tibetan plateau, China, Atmos. Environ., 42, 70-979, doi:10.1016/j.atmosenv.2007.10.018, 2008.

Fu, X., Feng, X., Wang, S., Rothenberg, S., Shang, L., Li, Z., and Qiu, G.: Temporal and spatial distributions of total gaseous mercury concentrations in ambient air in a mountainous area in southwestern China: Implications for industrial and domestic mercury emissions in remote areas in China, Sci. Total Environ., 407, 2306-2314, doi:10.1016/j.scitotenv.2008.11.053, 2009.

Fu, X., Feng, X., Dong, Z. Q., Yin, R. S., Wang, J. X., Yang, Z. R., and Zhang, H.: Atmospheric gaseous elemental mercury (GEM) concentrations and mercury depositions at a high-altitude mountain peak in south China, Atmos. Chem. Phys., 10, 2425-2437, doi:10.5194/acp-10-2425-2010, 2010a.

Fu, X., Feng, X., Zhu, W., Rothenberg, S., Yao, H., and Zhang, H.: Elevated atmospheric deposition and dynamics of mercury in a 
remote upland forest of Southwestern China, Environ. Pollut., 158, 2324-2333, doi:10.1016/j.envpol.2010.01.032, 2010b.

Grigal, J. A., Kolka, R. K., Fleck, J. A., and Nater, E. A.: Mercury budget of an upland-peatland watershed, Biogeochemistry, 50, 95-109, doi:10.1023/A:1006322705566, 2000.

Guo, Y., Feng, X., Li, Z., He, T., Yan, H., Meng, B., Zhang, J., and Qiu, G.: Distribution and wet deposition fluxes of total and methyl mercury in Wujiang reservoir Basin, Guizhou, China, Atmos. Environ., 42, 7096-7103, doi:10.1016/j.atmosenv.2008.06.006, 2008.

Huang, J., Kang, S., Zhang, Q., Jenkins, M., Guo, J., Zhang, G., and Wang, K.: Spatial distribution and magnification processes of mercury in snow from high-elevation glaciers in the Tibetan Plateau, Atmos. Environ., 46, 140-146, doi:10.1016/j.atmosenv.2011.10.008, 2012.

Keeler, G. J., Gratz, L. E., and Al-wali, K.: Long-term atmospheric mercury wet deposition at Underhill, Vermont, Ecotoxicology, 14, 71-83, doi:10.1007/s10646-004-6260-3, 2005.

Larssen, T., De Wit, H. A., Wiker, M., and Halse, K.: Mercury budget of a small forested boreal catchment in southeast Norway, Sci. Total Environ., 404, 290-296, doi:10.1016/j.scitotenv.2008.03.013, 2008.

Lee, Y. H., Bishop, K. H., and Munthe, J.: Do concepts about catchment cycling of methylmercury and mercury in boreal catchments stand the test of time? Six years of atmospheric inputs and runoff export at Svartberget, northern Sweden, Sci. Total Environ., 260, 11-20, doi:10.1016/S0048-9697(00)00538-6, 2000.

Lindberg, S. E., Zhang, H., Vette, A. F., Gustin, M. S., Barnett, M. O., and Kuiken, T.: Dynamic flux chamber measurement of gaseous mercury emission fluxes over soils, Part 2: effect of flushing flow rate and verification of a two-resistance exchange interface simulation model. Atmos. Environ, 36, 847859, doi:10.1016/S1352-2310(01)00502-7, 2002a.

Lindberg, S. E., Dong, W., and Meyers, T.: Transpiration of gaseous elemental mercury through vegetation in a subtropical wetland in Florida, Atmos. Environ., 36, 5207-5219, doi:10.1016/S13522310(02)00586-1, 2002b.

Lv, W., Zhang, H., Wang, W., Du, S., Wu, Y., He, P., and Xiao, L.: Characteristics of soil aggregates in different forestlands in Simian mountains, Chongqing, J. Soil Water Conserv., 24, $193-$ 197, doi:10.13870/j.cnki.stbcxb.2010.04.048, 2014.

Ma, M., Wang, D., Du H, Sun, R., Zhao Z., and Wei S.: Gaseous mercury emissions from subtropical forested and open field soils in a national nature reserve, southwest China, Atmos. Environ., 64,116-123, doi:10.1016/j.atmosenv.2012.09.038, 2013.
Ma, M., Wang, D., Sun, R., Shen, Y., and Huang L.: Atmospheric mercury deposition and its contribution of the regional atmospheric transport to mercury pollution at a national forest nature reserve, southwest China, Environ. Sci. Pollut. R., 22, 20007 20018, doi:10.1007/s11356-015-5152-9, 2015.

Qiu, G., Feng, X., Wang, S., and Shang, L.: Environmental contamination of mercury from $\mathrm{Hg}$-mining areas in Wuchuan, northeastern Guizhou, China, Environ. Pollut., 142, 549-558, doi:10.1016/j.envpol.2005.10.015, 2006.

Schwesig, D. and Matzner, E.: Dynamics of mercury and methylmercury in forest floor and runoff of a forested watershed in Central Europe, Biogeochemistry, 53, 181-200, doi:10.1023/A:1010600600099, 2001.

Sigler, J. M., Mao, H., and Talbot, R.: Gaseous elemental and reactive mercury in Southern New Hampshire, Atmos. Chem. Phys., 9, 1929-1942, doi:10.5194/acp-9-1929-2009, 2009.

Stamenkovic, J. and Gustin, M. S.: Nonstomatal versus Stomatal uptake of atmospheric mercury, Environ. Sci. Technol., 43,13671372, doi:10.1021/es801583a, 2009.

St. Louis, V. L., Rudd, W. M, Kelly, C. A., Hall, B. D., Rolfhus, K. R., Scott, K. J., Lindberg, S. E., and Dong, W.: Importance of the forest canopy to flux of methylmercury and total mercury to boreal ecosystems, Environ. Sci. Technol., 35, 3089-3098, doi:10.1021/es001924p, 2001.

Travnikov, O.: Contribution of the intercontinental atmospheric transport to mercury pollution in the Northern Hemisphere, Atmos. Environ., 39, 7541-7548, doi:10.1016/j.atmosenv.2005.07.066, 2005.

US EPA: Method 1631: Revision B, Mercury in water by Oxidation, Purge and Trap, and Cold Vapor atomic Fluorescence Spectrometry, United States Environmental Protection Agency, Washington, DC, USA, 1-33, 1999.

Wang, D., He, L., Shi, X., Wei, S., and Feng, X.: Release flux of mercury from different environmental surfaces in Chongqing, China, Chemosphere, 64, 1845-1854, doi:10.1016/j.chemosphere.2006.01.054, 2006.

Wang, S., Feng, X., Qiu, G., Fu, X., and Wei, Z.: Characteristics of mercury exchange flux between soil and air in the heavily air-polluted area, eastern Guizhou, China, Atmos. Environ., 41, 5584-5594, doi:10.1016/j.atmosenv.2007.03.002, 2007.

Zhu, J., Wang, D., Liu, X., and Zhang, Y.: Mercury fluxes from air/surface interfaces in paddy field and dry land, Appl. Geochemistry, 26, 249-255, doi:10.1016/j.apgeochem.2010.11.025, 2010 . 